\title{
A rapid micro-method for the screening and measurement of barbiturates and related compounds in plasma by gas-liquid chromatography
}

\author{
R. J. FLANAGAN AND G. WITHERS ${ }^{1}$
}

From the Poisons Unit, Guy's Hospital, London ${ }^{2}$

SYNOPSIS A rapid gas-chromatographic method has been developed for the determination of butobarbitone, amylobarbitone, hexabarbitone, pentobarbitone, quinalbarbitone, phenobarbitone glutethimide, and methaqualone in 'finger-prick' samples of plasma. This has been applied to the analysis of some of these drugs in plasma taken from patients after therapeutic dosage and overdosage.

Barbiturates and related hypnotics are commonly taken in overdosage and their rapid identification and measurement in plasma may be of assistance to the clinician. At present the method of choice is solvent extraction followed by gas-liquid chromatography, since this will give both a tentative identification and an accurate measurement in one step. Several such procedures have been reported (Braddock and Marec, 1965; Leach and Toseland, 1968; McMartin and Street, 1966; Reith, van der Heide, and Zwaal, 1965; Street and McMartin, 1963; Sunshine and Maes, 1968) but only those of Jain, Fontan, and Kirk (1964), Anders (1966), MacGee (1971), Scott (1971), and Kållberg, Agureel, Jalling, and Boréus (1971) can be quickly performed on less than the 1 to $5 \mathrm{ml}$ of whole blood or plasma required by other methods. Moreover, these volumes are not always readily obtainable, especially from young children.

Jain, Fontan, and Kirk (1964) took $0.1 \mathrm{ml}$ of whole blood, extracted this four times with $0.5 \mathrm{ml}$ of solvent and chromatographed the combined extract. The accuracy of the method was indeterminate since no internal standard was incorporated and no recovery studies were described.

Anders (1966) carried out solvent extraction of $0.1 \mathrm{ml}$ of acidified whole blood with $0.1 \mathrm{ml}$ of chloroform in $5 \mathrm{ml}$ centrifugal separators. Aliquots of the chloroform layer were withdrawn into a microsyringe, via a rubber septum situated at the base of 'Now at School of Pharmacy, University of London, Brunswick Square, London, WC1.

'Reprints from Poisons Unit, New Cross Hospital, Avonley Road, London, SE14 SER.

Received for publication 17 August 1972. the separator, and these were injected directly onto the gas chromatograph. The separators are expensive, difficult to obtain, and not easily cleaned. Furthermore, the extracts may become contaminated by compounds dissolved out of the septum, although this possibility has been minimized by the insertion of an aluminium disc directly above the septum.

In the methods of both MacGee (1971) and Scott (1971), extraction was performed using a solvent containing a standard mixture of barbiturates. The chromatogram obtained from this extract was compared to that obtained from the standard mixture alone. Measurement of barbiturate in the sample was achieved using an adjacent barbiturate peak as an internal standard. Although a novel approach, the wisdom of deliberately introducing a multitude of peaks onto the chromatogram is questionable. Gas-chromatographic analysis of blood and plasma samples is notoriously susceptible to interference from contaminants of solvents and glassware and from other blood components. The degree of purity of individual extracts would be indeterminate using these procedures.

Kållberg et al (1971) recently reported a method for the estimation of phenobarbitone in $100 \mu \mathrm{l}$ plasma samples, but the behaviour of other barbiturates in this system was not examined.

The method now described is a modification of that of Anders (1966). The use of Dreyer tubes (to BS 625), which are cheap and therefore disposable, avoids any cross-contamination of samples. An additional refinement is the inclusion of an internal standard to eliminate the possibility of injection errors. 


\section{Gas Chromatography}

A Pye series 104 dual-column gas chromatograph equipped with a flame ionization detector and a $1 \mathrm{mv}$ Perkin-Elmer 159 recorder was used. The column was a $5 \mathrm{ft} \times \frac{1}{4}$ in. OD coiled glass tube which had been silanized with a $5 \%$ solution of dimethyldichlorosilane in benzene over a period of 24 hours. Glass-wool was silanized in the same solution. After drying overnight at $100^{\circ}$ the column was packed with $4 \%$ cyclohexanedimethanol succinate (CDMS) (Perkin-Elmer Limited, Beaconsfield, Buckinghamshire) on 85-100 mesh Diatomite C.Q. (J.J.'s Chromatography Limited, King's Lynn, Norfolk) according to the method of Berry (1969). The column was conditioned for 48 hours at $240^{\circ}$ with a nitrogen flow rate of $60 \mathrm{ml} /$ minute. Thereafter, the column was tapped down, more packing material added, and reconditioned for a further $\mathbf{4 8}$ hours before use.

The instrument settings were as follows: column oven temperature $225^{\circ}$; injection port setting 2 ; detector oven temperature $250^{\circ}$; nitrogen (carrier gas) flow rate $60 \mathrm{ml} / \mathrm{min}$; attenuation $\times 50$; hydrogen flow rate $60 \mathrm{ml} / \mathrm{min}$; air flow rate $600 \mathrm{ml} / \mathrm{min}$. If the presence of phenobarbitone was suspected in the sample, a column oven temperature of $235^{\circ} \mathrm{C}$ was selected.

The retention times of the drugs under study are given in Table I.

\begin{tabular}{|c|c|c|c|}
\hline \multicolumn{2}{|c|}{$\begin{array}{l}\text { Column Oven Temperature } \\
225^{\circ}\end{array}$} & \multicolumn{2}{|c|}{$\begin{array}{l}\text { Column Oven Temperature } \\
235^{\circ}\end{array}$} \\
\hline Drug & $\begin{array}{l}\text { Retention } \\
\text { Times in } \\
\text { Minutes }\end{array}$ & Drug & $\begin{array}{l}\text { Retention } \\
\text { Times in } \\
\text { Minutes }\end{array}$ \\
\hline $\begin{array}{l}\text { Butobarbitone } \\
\text { Amylobarbitone } \\
\text { Hexabarbitone } \\
\text { Glutethimide } \\
\text { Pentobarbitone } \\
\text { Quinalbarbitone } \\
\text { Tetraphenylethylene } \\
\text { Methaqualone }\end{array}$ & $\begin{array}{l}3 \cdot 5 \\
3 \cdot 8 \\
3 \cdot 8 \\
4 \cdot 1 \\
4 \cdot 2 \\
5 \cdot 1 \\
6 \cdot 9 \\
8 \cdot 1\end{array}$ & $\begin{array}{l}\text { Tetraphenylethylene } \\
\text { Phenobarbitone }\end{array}$ & $\begin{array}{r}4 \cdot 3 \\
12 \cdot 7\end{array}$ \\
\hline
\end{tabular}

Table I Retention times

\section{EXTRACTION PROCEDURES}

The following reagents were employed: $4.0 \mathrm{M}$ sodium dihydrogen orthophosphate (AR grade) in distilled water (phosphate buffer); $10 \mu \mathrm{g} / \mathrm{ml}$ tetraphenylethylene (TPE) (available from Koch-Light Laboratories, Colnbrook, Buckinghamshire) in chloroform (AR grade, redistilled).

Five $\mu$ lof buffer solution was introduced into a clean Dreyer tube using a Hamilton repeating dispenser fitted to a $250 \mu$ l gas-tight syringe (available from Field Instruments Limited, Richmond, Surrey). A 500 $\mu l$ aliquot of the plasma sample was added via an Eppendorf semi-automatic pipette (available in the UK from V. A. Howe and Company, London, W.11) $\overrightarrow{\vec{s}}$ and finally $50 \mu \mathrm{l}$ of $10 \mu \mathrm{g} / \mathrm{ml}$ TPE solution waso dispensed into the tube using a Hamilton repeatingo mechanism fitted to a $2500 \mu \mathrm{l}$ gas-tight syringe ( $5 \mu \mathrm{g} / \mathrm{ml}$ TPE solution was used if the presence of phenobarbitone in the sample was suspected).

The contents of the tube were mixed thoroughly for 30 seconds on a Whirlmixer and centrifuged for $\overline{0}$ two to three min at 2000 to $3000 \mathrm{rpm}$.

The presence of a lipoprotein interface between the aqueous and organic layers made careful with drawal of the extract essential. To prevent con tamination or blockage of the syringe needle, a smaler quantity of air was taken into the syringe and, aftero passing the needle through the protein layer, waso slowly expelled.

A suitable quantity of extract was taken up and? on withdrawing the sample, the outside of the needle was wiped with a tissue before injection onto the column of the gas chromatograph.

\section{QUANTITATION}

For each of the drugs under study, a range 85 standard solutions in redistilled chloroform prepared. These standards contained from 5,000 $50 \mu \mathrm{g} / \mathrm{ml}$ of drug and $10 \mu \mathrm{g} / \mathrm{ml}$ of TPE, with thes exception of phenobarbitone standards which con-o tained $5-100 \mu \mathrm{g} / \mathrm{ml}$ of the drug and $5 \mu \mathrm{g} / \mathrm{ml}$ of TPE. The ratio of the peak height of drug to the@ peak height of the internal standard was linear in $\overrightarrow{\overrightarrow{0}}$ each case over the stated concentration range. Cali- -3 bration graphs were prepared by injecting 3-5 $\mu$ 를 aliquots of these solutions after injection of unknown samples.

Figures 1 to 4 illustrate the responses and separations obtained with the standard chloroform solutions of the drugs under study.

\section{Results and Discussion}

\section{RECOVERY STUDIES}

Standards containing phenobarbitone at a concentration of 10,20 , and $50 \mu \mathrm{g} / \mathrm{ml}$ were prepared in $N$ heparinized bovine plasma. Concentrations of $5,10, \mathrm{~N}$ and $20 \mu \mathrm{g} / \mathrm{ml}$ were used for the other drugs under study.

These standards were taken through the extraction procedure described above and the results obtained을 are shown in Table II. It can be seen that recoveries were of the order of $90 \%$, with a standard deviation ${ }^{-}$ of $8 \%$ or less for all drugs, and were uniform overthe concentration range studied. 


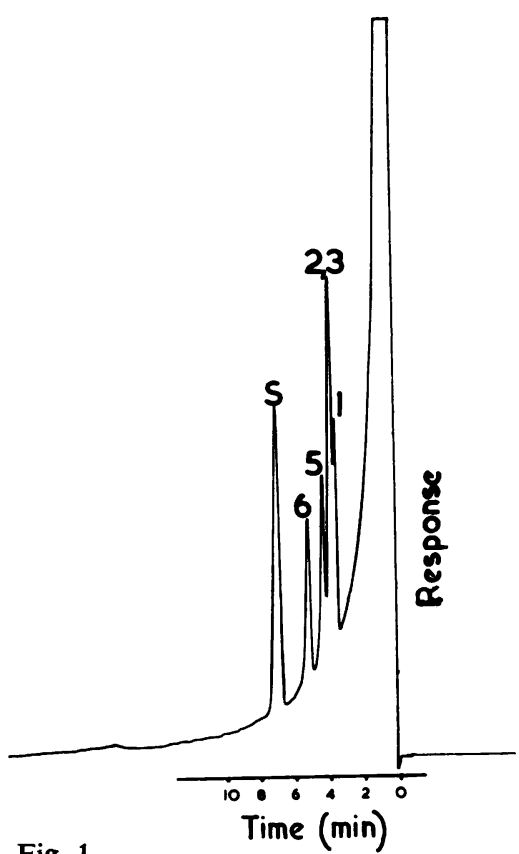

Fig. 1.

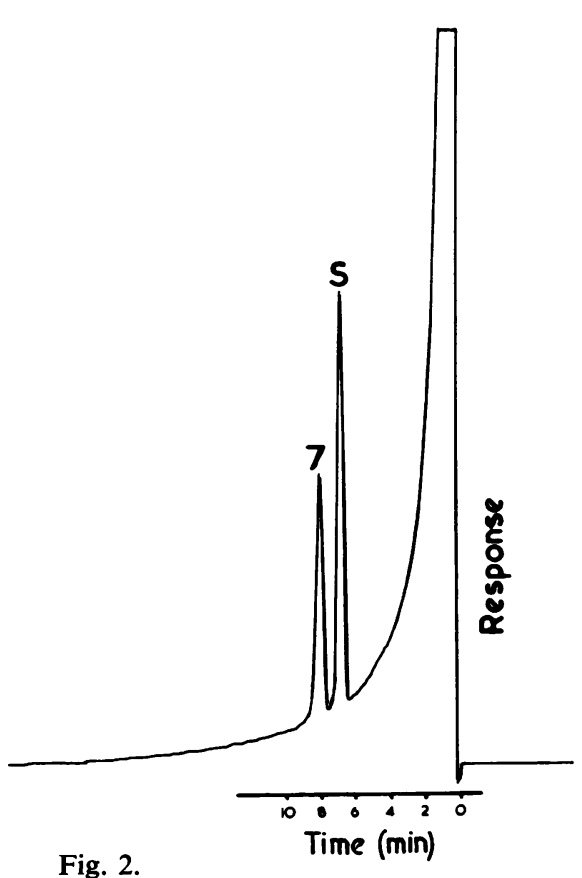

Fig. 2.

Fig. 1 Two $\mu \mathrm{l}$ injection of standard barbiturate mixture containing $10 \mu \mathrm{g} / \mathrm{ml}$ of (1) butobarbitone, (2) amylobarbitone, (3) hexabarbitone, (5) pentobarbitone, (6) quinalbarbitone, and $(S)$ tetraphenylethylene.

Fig. 2 Three $\mu \mathrm{l}$ injection of standard methaqualone solution, containing $10 \mu \mathrm{g} / \mathrm{ml}$ methaqualone (7) and $10 \mu \mathrm{g} / \mathrm{ml}$ tetraphenylethylene $(S)$.

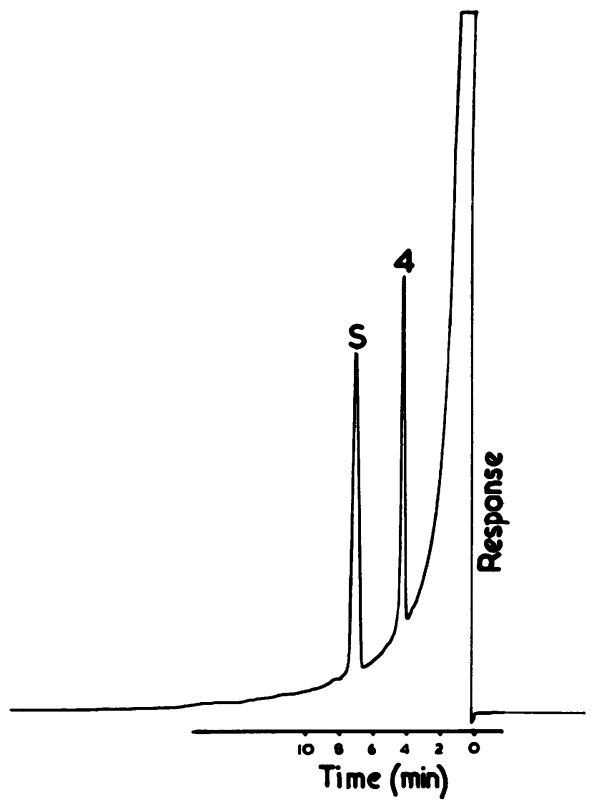

Fig. 3.

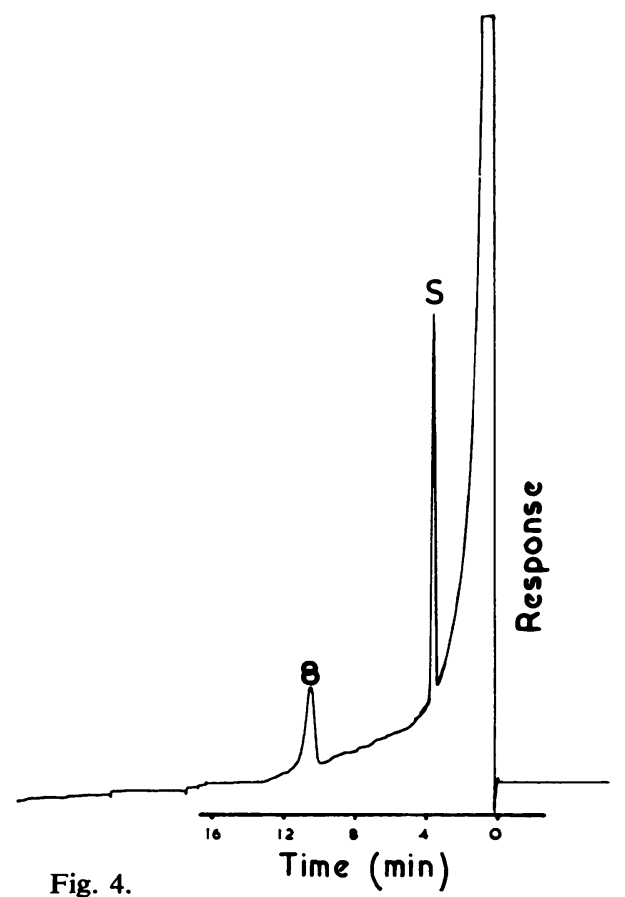

Fig. 3 Three $\mu \mathrm{l}$ injection of $10 \mu \mathrm{g} / \mathrm{ml}$ glutethimide standard (4) with $10 \mu \mathrm{g} / \mathrm{ml}$ tetraphenylethylene $(S)$.

Fig. 4 Three $\mu \mathrm{l}$ injection of $5 \mu \mathrm{g} / \mathrm{ml}$ standard phenobarbitone (8) solution. Internal standard $=5 \mu \mathrm{g} / \mathrm{ml}$ tetraphenylethylene $(S)$. 


\begin{tabular}{lll}
\hline Drug & \% Recovery & $\begin{array}{l}\text { Standard } \\
\text { Deviation (\%) }\end{array}$ \\
\hline Butobarbitone & 83 & 5 \\
Amylobarbitone & 91 & 8 \\
Pentobarbitone & 94 & 5 \\
Hexabarbitone & 94 & 4 \\
Quinalbarbitone & 85 & 8 \\
Phenobarbitone & 78 & 6 \\
Methaqualone & 88 & 5 \\
Glutethimide & 100 & 7 \\
\hline
\end{tabular}

Table II Recoveries of added drug from heparinized bovine plasma over the concentration range 5-20 $\mathrm{\mu g} / \mathrm{ml}$ (phenobarbitone $10-50 \mu \mathrm{g} / \mathrm{ml})^{1}$

${ }^{1}$ Each result represents the mean of 15 samples.

\section{COMPARISON WITH THE STANDARD MACRO-} SCALE EXTRACTION PROCESS

The micro-method has been compared-with respect to results obtained, contamination in extract, and time taken to perform in duplicate-with a more elaborate procedure (Berry, to be published). In this method $1 \mathrm{ml}$ of acidified plasma was extracted with $25 \mathrm{ml}$ of chloroform; barbiturates present were backextracted into $5 \mathrm{ml}$ of $0.5 \mathrm{~N}$ aqueous sodium hydroxide solution, and this was acidified and reextracted with a further $15 \mathrm{ml}$ of chloroform. One $\mathrm{ml}$ of TPE solution (internal standard) was added and the extract evaporated to dryness. Finally, the residue was taken up in $0.1 \mathrm{ml}$ of chloroform and chromatographed on the system described previously.

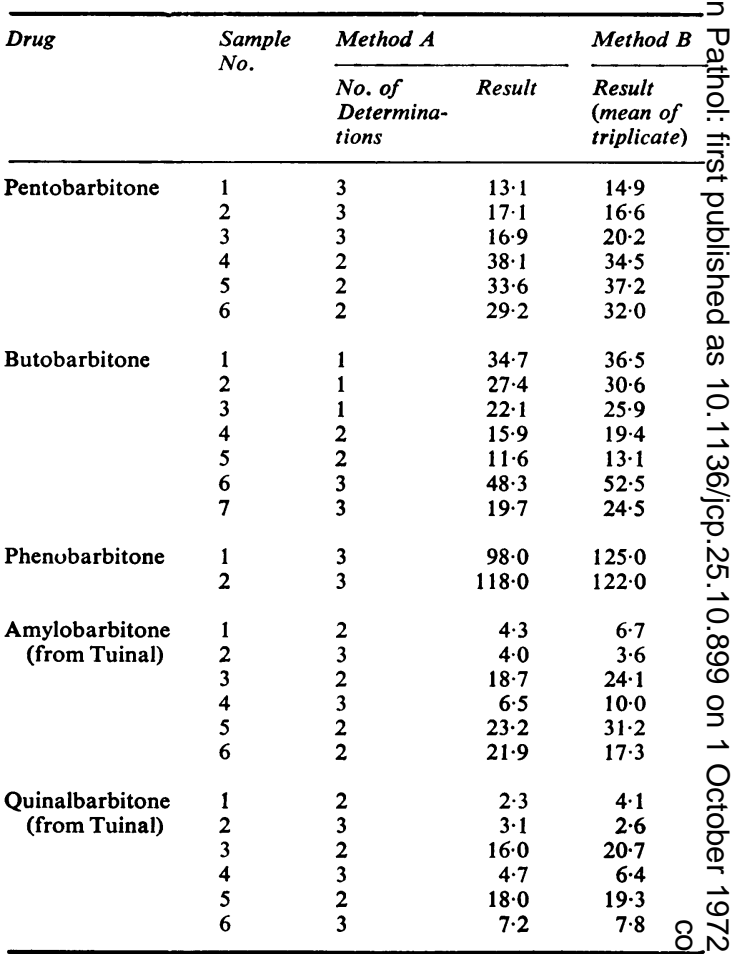

Table III A comparison of results obtained using the method of Berry $(A)$ and the micro-method $(B)^{1}$

${ }^{1}$ All results in $\mu \mathrm{g} / \mathrm{ml}$, corrected for extraction losses.

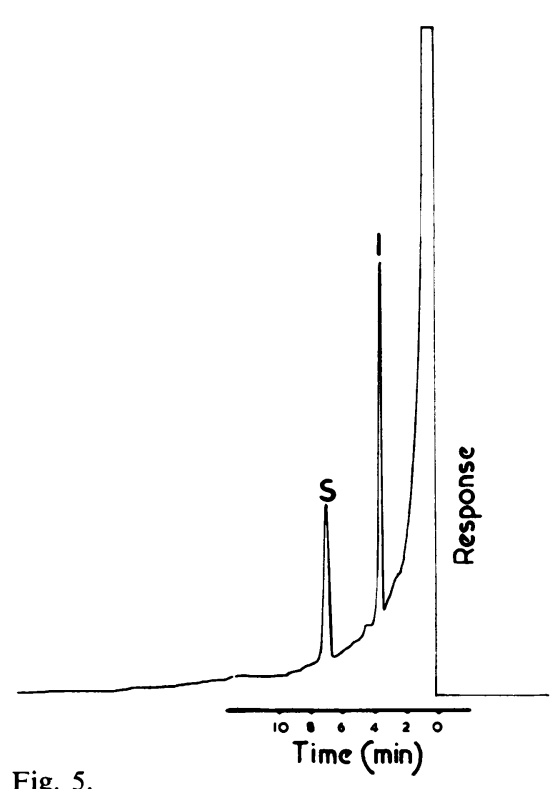

Fig. 5.

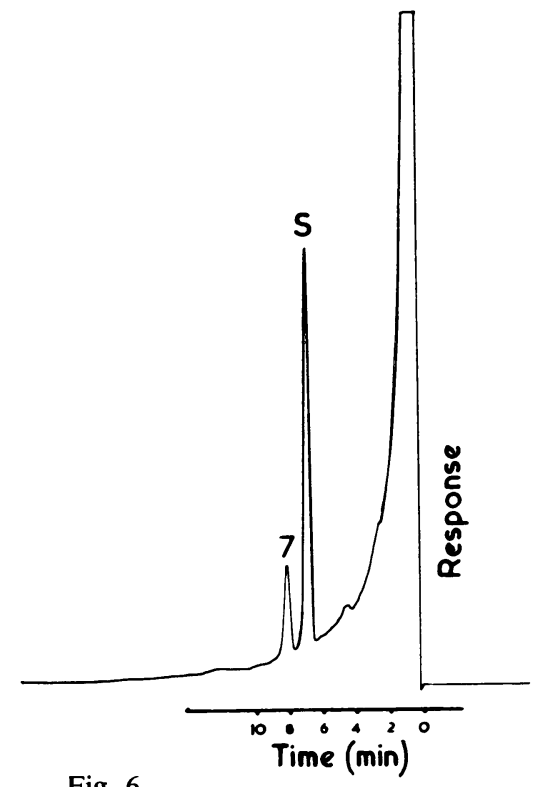

Fig. 6 .
Fig. 5 One $\mu$ injection of extract of butobarbitone overdose sample. Internal standard $(S) 10 \mu \mathrm{g} / \mathrm{ml}$ tetraphenylethylene.

Fig. 6 Three $\mu$ linjection of sample from case of suspected methaqualone ingestion. Internal standard $10 \mu \mathrm{g} / \mathrm{ml}$ tetraphenylethylene. 
The comparison of results obtained by the two procedures for barbiturate estimation is shown in Table III.

Both methods yielded spurious peaks on the chromatograms, but the micro-method gave a considerably cleaner extract from many samples (Figs. 5 and 6). In neither case were peaks encountered that interfered with the analysis, except sometimes at levels below $5 \mu \mathrm{g} / \mathrm{ml}$ (Fig. 7 could indicate a trace of pentobarbitone). (The micro-method involves no concentration of organic phase-this could contribute towards extract cleanliness.)

At the higher column oven temperature used for the measurement of phenobarbitone a contaminant peak with twice the retention time of the drug was consistently found when using the rapid method (Fig. 8). This difficulty was overcome by carefully timing the sample injections. At $225^{\circ} \mathrm{C}$ this peak lost much definition and could be injected over quite easily.

Finally, the micro-method took five minutes to extract a sample in duplicate; the long-extraction procedure took upwards of one hour.

EXTRACTION TIME

Experiments were performed to examine the effect of extraction time on recovery and clarity of extract. It was found that 30 seconds was the optimum time period. Mixing for 60 seconds, or 120 seconds, increased the amount of contamination in the extract, but did not significantly effect the recovery of the drug.

\section{REPRODUCIBILITY}

The simplicity of the method allows highly reproducible results to be obtained (Table IV). Since the whole process takes place in a single tube, no losses of drug occur by multiple transfers of extracts between tubes. Furthermore, as there is no evaporation stage in the method, no losses can occur through solvent splashing out of the tube.

Sources of error can arise when measuring out the plasma and extracting the solvent. These are minimized by correct use of the Hamilton dispenser and the Eppendorf pipette, which in our hands have been shown to deliver volumes reproducible tc within $\pm 2 \%$.

POSSIBLE INTERFERENCE FROM OTHER DRUGS Here, consideration is limited to those drugs commonly occurring in overdose at concentrations of, say, $5 \mu \mathrm{g} / \mathrm{ml}$ or greater. Acetylsalicylic acid, sali-

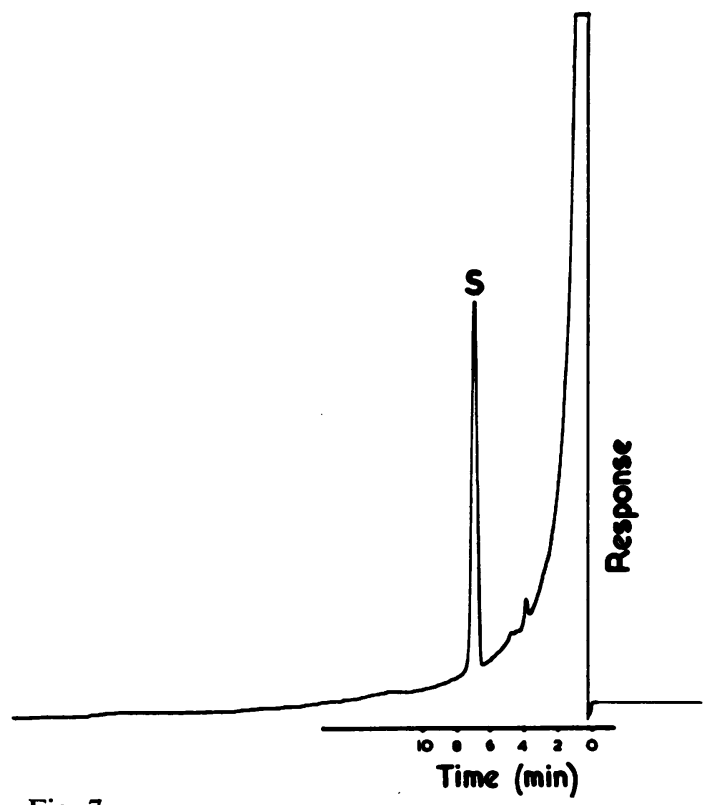

Fig. 7.

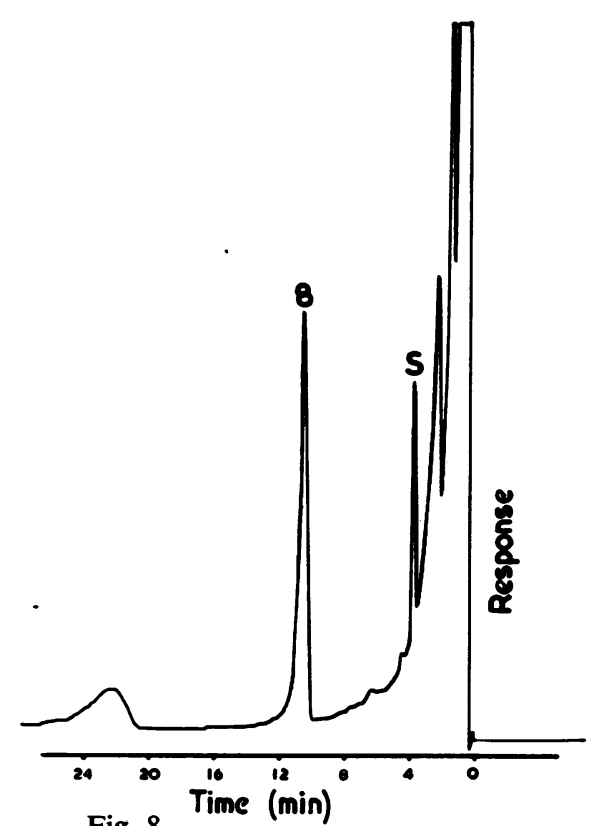

Fig. 8.

Fig. 7 Three $\mu$ l injection of extract of plasma sample screened for presence/absence of drugs under study. $S=10 \mu \mathrm{g} / \mathrm{ml}$ tetraphenylethylene.

Fig. 8 Two $\mu l$ of extract of plasma sample from phenobarbitone overdose case. Internal standard $5 \mu \mathrm{g} / \mathrm{ml}$ tetraphenylethylene. 


\begin{tabular}{|c|c|c|c|}
\hline & Sample & Peak Ratio & $\%$ Recovery \\
\hline \multirow{5}{*}{$5 \mu \mathrm{g} / \mathrm{ml}$} & (A & $0 \cdot 30$ & 92 \\
\hline & B & 0.28 & 87 \\
\hline & $\left\{\begin{array}{l}\mathrm{C} \\
\text {. }\end{array}\right.$ & 0.27 & 91 \\
\hline & D & $0 \cdot 28$ & 93 \\
\hline & $E$ & $0 \cdot 25$ & 83 \\
\hline \multirow{5}{*}{$10 \mu \mathrm{g} / \mathrm{ml}$} & CA & $0 \cdot 54$ & 85 \\
\hline & B & 0.56 & 87 \\
\hline & $\mathrm{C}$ & 0.58 & 90 \\
\hline & D & 0.59 & 93 \\
\hline & $\mathrm{E}$ & 0.56 & 88 \\
\hline \multirow{5}{*}{$20 \mu \mathrm{g} / \mathrm{ml}$} & CA & $1 \cdot 13$ & 85 \\
\hline & B & 0.97 & 74 \\
\hline & C & $1 \cdot 18$ & 91 \\
\hline & D & $1 \cdot 14$ & 87 \\
\hline & $\mathrm{E}$ & $1 \cdot 14$ & 87 \\
\hline
\end{tabular}

Table IV Results obtained from analysis of methaqualone bovine plasma standards of 5, 10, and 20) $\mathrm{\mu g} / \mathrm{ml}$ concentration

\begin{tabular}{lll}
\hline Drug & Retention Time & Response \\
\hline Phenacetin & 0.42 & Poor \\
Butobarbitone & 0.49 & Good \\
Quinalbarbitone & 0.72 & Good \\
Ethotoin & 0.84 & Good \\
Phenazone & 0.89 & Poor \\
Meprobamate & 0.97 & Very poor \\
\hline
\end{tabular}

Table V Drugs extracted and chromatographed by the system under study ${ }^{1}$

${ }^{1}$ Retention times relative to tetraphenylethylene at column oven temperature $225^{\circ} \mathrm{C}$.

cylic acid, paracetamol, phenytoin, methyprylone, and ethchlorvynol have been found not to interfere.

The four drugs which have been demonstrated to be both extracted and chromatographed are shown in Table $\mathrm{V}$.

\section{A P PLICATION}

The method described here offers a rapid, sensitive procedure for the detection and estimation of barbiturates, methaqualone, and glutethimide in small quantities of plasma. As a screening device it can eliminate, or suggest, the presence of a barbiturate or related drug, in 10 minutes. A complete quantitative analysis in duplicate takes less than 30 minutes.

Since a single retention time on a gas-chromatographic system is not necessarily an adequate criterion of identification it is recommended that, in cases of drug overdose, the analysis should be accompanied by more specific qualitative procedure such as thin-layer chromatography. Here, also, the extraction can be speeded up by mixing the require amount of plasma with proportionate volumes of chloroform and buffer.

The adaptability of the extraction is furthe्f. demonstrated by its use in estimating barbiturate concentrations in $20 \mu \mathrm{l}$ plasma samples as, f $\leftrightarrow$ example, from rodents.

We should like to thank Dr R. Goulding and Dr B. Widdop for their continuous advice and encourag $\overrightarrow{e_{0}}$ ment and Miss S. Enness for her skilled technic용 assistance. We should also like to express oọ gratitude to Ciba Laboratories Limited, Horshan Sussex, for their gift of pure glutethimide and to Roussel Laboratories Limited, Wembley Parlo Middlesex, for their gift of pure methaqualone.

References

Anders, M. W. (1966). Rapid micromethod for gas chromatographis determination of blood barbiturates. Analyt. Chem., 38 1945-1947.

Berry, D. J. (1969). Gas chromatographic determination of meth qualone, 2-methyl-3-o-tolyl-4(3H)-quinazolinone, at ther@ peutic levels in human plasma. $J$. Chromatogr., 42, 39-44.

Berry, D. J. (1973). Gas chromatographic analysis of the commone prescribed barbiturates at therapeutic and overdose leve्ठ if plasma and urine. (In preparation.)

Braddock, L. I., and Marec, N. (1965). The gas chromatograrhe analysis of sub-microgram quantities of barbiturates using flame ionization detector. J. gas Chromatogr., 3, 274-27 7

Jain, N. C., Fontan, C. R., and Kirk, P. L. (1964). Rapid extractio method for barbiturates from blood for gas-liquid chromato graphic analysis. Microchem. J., 8, 28-34.

Kållberg, N., Agurell, S., Jalling, B., and Boréus, L. O. (1971). Rap色 gas chromatographic determination of phenobarbital in sma\# plasma samples. Europ. J. clin. Pharmacol., 3, 185-188.

Leach, H., and Toseland, P. A. (1968). The determination of barbitu ates and some related drugs by gas chromatography. Clith chim. Acta, 20, 195-203.

MacGee, J. (1971). Rapid identification and quantitative determinc tion of barbiturates and glutethimide in blood by GLC. Clivin. Chem., 17, 587-591.

McMartin, C., and Street, H. V. (1966). Gas liquid chromatography of submicrogram amounts of drugs. II. Analysis of barbiturates and related drugs in biological media. J. Chromatogr., 23. 232-241.

Reith, J. F., van der Heide, R. F., and Zwaal, R. F. A. (1965). Gas chromatography of barbiturates in blood. (Dutch). Pharm. Weekblad., 100, 219-227.

Scott, P. H. (1971). Simultaneous estimation and identification of blood barbiturate by gas chromatography. Ann. clin. Biochem 8, $105-108$.

Street, H. V., and McMartin, C. (1963). Quantitative estimation an identification of barbiturates in blood in emergency case Oㅇ Nature (Lond.), 199, 456-459.

Sunshine, I., and Maes, R. (1968). An evaluation of methods for the determination of barbiturates in biological materials. Clip Toxicol., 1, 281-296. 